\title{
Pharmacogenetics of Selective Serotonin Reuptake Inhibitors and Associated Adverse Drug Reactions
}

\begin{abstract}
Kelan L. H. Thomas, Pharm.D., and Vicki L. Ellingrod, Pharm.D., FCCP
The selective serotonin reuptake inhibitors (SSRIs) have become one of the most widely prescribed classes of drugs. They are relatively safe for the pharmacologic treatment of various psychiatric disorders; however, certain patients cannot tolerate some adverse drug reactions associated with this drug class. In addition, clinicians currently have no way to predict who will respond appropriately to a given SSRI, and the paradigm of trial and error is especially distressing for patients with mental illness. Pharmacogenetic association studies may provide insight into which genetic polymorphisms might be clinically relevant for individualizing pharmacotherapeutic regimens. Thus, we reviewed and summarized the literature regarding the pharmacogenomics of SSRI-associated adverse drug reactions. This growing body of knowledge may inform subsequent design of pharmacogenetic studies with respect to adverse drug reactions. As we appreciate the many pharmacologic mechanisms related to adverse drug reactions and gain polymorphic functional data, we will have opportunities to refine hypotheses for future pharmacogenetic association analyses.
\end{abstract}

Key Words: selective serotonin reuptake inhibitor, SSRI, pharmacogenetics, adverse drug reactions, antidepressants.

(Pharmacotherapy 2009;29(7):822-831)

\section{OUTLINE}

Serotonergic Genes

Serotonin Transporter Gene (SLC6A4)

Serotonin Transporter Promoter Region (SERTPR)

Variant

Serotonin Transporter, Second Intron Variable

Number of Tandem Repeats (STin2)

Serotonin 2A Receptor Gene (HTR2A)

HTR2A Variants T102C (rs6313) and -1438G/A

Serotonin 3A Receptor Gene (HTR3A)

Serotonin 3B Receptor Gene (HTR3B)

Tryptophan Hydroxylase Gene (TPH)

Dopaminergic Genes

Glutamatergic Genes

From the Clinical Pharmacogenomics Laboratory, College of Pharmacy (both authors), and the Department of Psychiatry, College of Medicine (Dr. Ellingrod), University of Michigan, Ann Arbor, Michigan.

Address reprint requests to Vicki L. Ellingrod, Pharm.D., BCPP, FCCP, Clinical Pharmacogenomics Laboratory, College of Pharmacy, University of Michigan, 428 Church Street, Ann Arbor, MI 48109-1065; e-mail: vellingr@umich.edu.
Monoaminergic Genes

Monoamine Oxidase A Gene (MAOA)

Cyclic Adenosine 3',5'-Monophosphate Response

Element Binding Protein 1 Gene (CREB1)

Metabolic Genes

Cytochrome P450 2D6 Gene (CYP2D6)

Cytochrome P450 2C19 Gene (CYP2C19)

Emerging Trends

Conclusion

Selective serotonin reuptake inhibitors (SSRIs) have become one of the most widely prescribed classes of drugs. Antidepressants took over the top ranking for prescriptions dispensed in the United States in 2007, with 232.7 million. ${ }^{1}$ Overall, the SSRIs have fewer adverse drug reactions than the other classes of antidepressants, such as tricyclic or heterocyclic antidepressants and monoamine oxidase inhibitors. However, some patients discontinue therapy because of intolerable adverse drug reactions. Clinicians currently have no way to predict who will respond appropriately to a given SSRI, and the paradigm of trial and error is 
especially distressing for patients with mental illness. Once SSRI therapy is started, 4-8 weeks may be required to establish efficacy. During this period, adverse events may cause some patients to stop treatment before their symptoms of depression improve. However, such reactions might be avoided if clinicians could predict them on the basis of a patient's genetic profile and, thus, individualize drug therapy.

Most of the pharmacogenetics literature related to SSRI use has focused on efficacy as the primary outcome. A thorough review of this literature recognized the fundamental challenge of selecting appropriate candidate polymorphisms for making efficacy associations when the exact mechanism by which SSRIs reduce depression symptoms is not entirely certain. ${ }^{2}$

Candidate polymorphisms for adverse drug reactions have traditionally been selected on the basis of their potential involvement in the pharmacokinetic or pharmacodynamic properties of SSRIs. Because it is easiest to objectively measure plasma concentrations and pharmacokinetic parameters, much initial attention focused on metabolic enzymes, particularly those in the cytochrome P450 (CYP) family. In the past few years, researchers began to question the clinical relevance of this information for SSRIs due to a wide therapeutic index and the lack of evidence reliably supporting a link between tolerability and plasma concentrations. ${ }^{3}$ Most recently, though, association studies of adverse drug reactions have focused on the pharmacodynamic effects of these drugs that may be mediated by alterations in transporters and postsynaptic receptors due to genetic variation.

This review summarizes the current pharmacogenetic studies that were designed to test associations between SSRI-related adverse drug reactions and genetic variation, as this body of literature is expanding quickly in the 21 st century. However, it has many limitations, as most of these studies are retrospective or have open-label designs, or are case reports. Regardless, the combined results of these studies illustrate trends observed from pharmacogenetic association analyses as they relate to global and specific adverse drug reactions. To compare results across the genetic polymorphisms tested, we categorized each study according to the drug-induced adverse drug reactions and the specific SSRIs investigated.

\section{Serotonergic Genes}

\section{Serotonin Transporter Gene (SLC6A4)}

The serotonin transporter (SERT) is the primary target for SSRIs; therefore, the gene that encodes SERT, SLC6A4, is an obvious candidate for evaluations of efficacy and adverse drug reactions. Most SSRI pharmacogenetic studies of adverse drug reactions have focused on SLC6A4. In particular, the gene-linked polymorphic promoter region with a 44-base pair insertion-deletion, called SERTPR, has a long (L) variation of a 16repeat sequence and a short (S) variation of 14 repeats that has been associated with lower levels of genetic transcription. ${ }^{4}$ The $\mathrm{L}$ allele has been

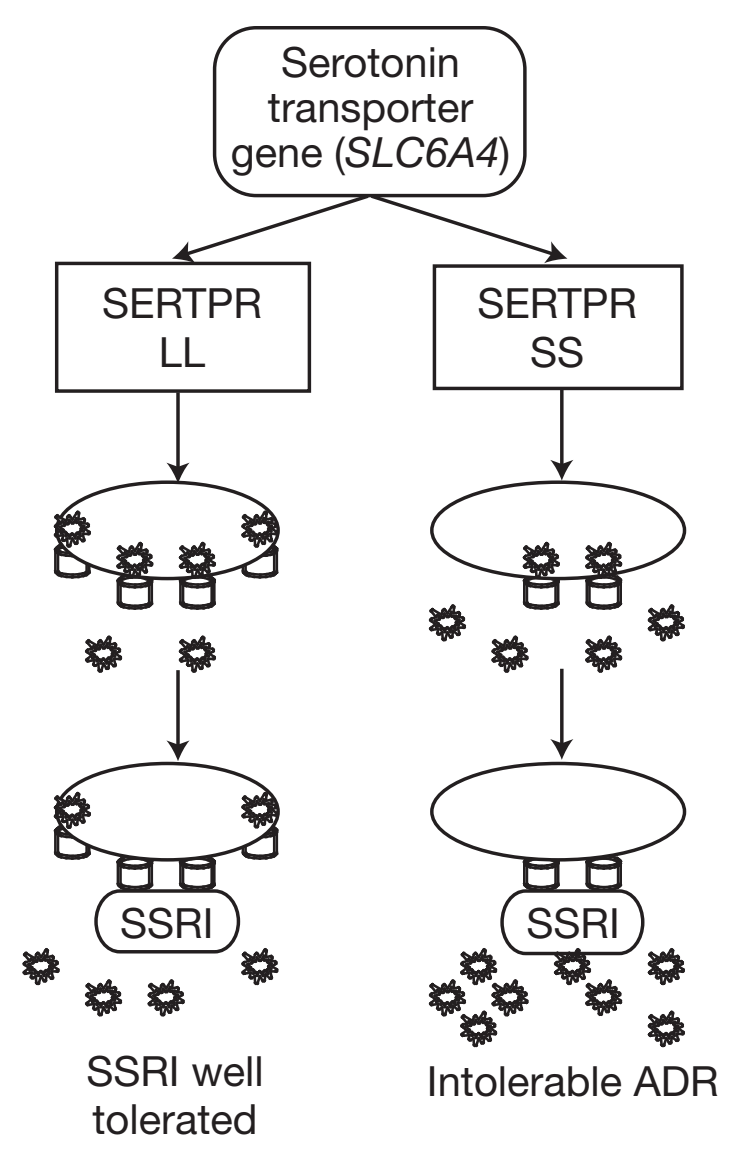

SERT 5-HT

Figure 1. Theoretical mechanism for increased selective serotonin reuptake inhibitor (SSRI)-induced adverse drug reactions (ADRs) with the SS genotype at the serotonin transporter (SERT) promoter region (SERTPR). The net effect is an overabundance of postsynaptic serotonin (5-HT): SERTPR SS genotype decreases SERT density, which decreases 5-HT reuptake, thereby allowing SSRI blockade to greatly increase 5-HT in the synapse that results in intolerable ADRs. The left side of the figure illustrates the mechanism for the LL genotype: SERTPR LL genotype increases SERT density, which increases 5-HT reuptake, thereby allowing SSRI blockade to mildly increase 5-HT in the synapse that results in well-tolerated SSRI therapy. 
Table 1. Summary of Studies Related to SLC6A4 Variants SERTPR and STin2

\begin{tabular}{|c|c|c|}
\hline $\begin{array}{l}\text { Polymorphism, Study } \\
\text { Design, Duration, } \\
\text { and Population }\end{array}$ & SSRI & Results \\
\hline \multicolumn{3}{|l|}{ SERTPR, STin2 } \\
\hline $\begin{array}{l}\text { Prospective, } 6 \text { wks, } \\
\text { Japanese }(\mathrm{n}=54)^{7}\end{array}$ & Fluvoxamine & No associations with nausea were noted \\
\hline $\begin{array}{l}\text { Prospective, } \geq 6 \text { wks, } \\
\text { Dutch }(\mathrm{n}=209)^{15}\end{array}$ & $\begin{array}{l}\text { Fluoxetine, paroxetine, sertraline, } \\
\text { citalopram, fluvoxamine }\end{array}$ & No associations with total ADRs were noted \\
\hline \multicolumn{3}{|l|}{ SERTPR } \\
\hline $\begin{array}{l}\text { Prospective, } 12 \text { wks, } \\
\text { American }(\mathrm{n}=36)^{8}\end{array}$ & Fluoxetine & $\begin{array}{l}\text { SS genotype associated with increased insomnia } \\
(78 \% \text { vs } 22 \%, p=0.005) \text { and agitation }(67 \% \text { vs } 7 \% \text {, } \\
\text { p=0.001) vs LL and SL genotypes }\end{array}$ \\
\hline $\begin{array}{l}\text { Prospective, } 5 \text { days, } \\
\text { German }(\mathrm{n}=22)^{9}\end{array}$ & Paroxetine, citalopram & $\begin{array}{l}\text { LL genotype associated with increased nighttime } \\
\text { motor activity }(\mathrm{p}<0.001)\end{array}$ \\
\hline $\begin{array}{l}\text { Prospective, } 8 \text { wks, } \\
\text { American }(\mathrm{n}=121)^{10}\end{array}$ & Paroxetine & $\begin{array}{l}\text { Number of S alleles had linear relationship with } \\
\text { discontinuation (SS 50\%, LL 12\%, SL 23\%; }<<0.05 \\
\text { for all time points); SS genotype also associated } \\
\text { with increased ADR severity vs LL ( } \mathrm{p}=0.02)\end{array}$ \\
\hline $\begin{array}{l}\text { Prospective, } 6 \text { wks, } \\
\text { Australian and } \\
\text { Malaysian }(n=35)^{11}\end{array}$ & Sertraline & No associations with ADRs were noted \\
\hline $\begin{array}{l}\text { Prospective, } 6 \text { wks, } \\
\text { Japanese }(n=100)^{12}\end{array}$ & Paroxetine, fluvoxamine & $\begin{array}{l}\text { No associations with discontinuation, nausea, or } \\
\text { total ADRs were noted }\end{array}$ \\
\hline $\begin{array}{l}\text { Retrospective, case- } \\
\text { control, Swedish } \\
(n=19)^{13}\end{array}$ & $\begin{array}{l}\text { Fluoxetine, paroxetine, sertraline, } \\
\text { citalopram, fluvoxamine }\end{array}$ & $\begin{array}{l}\text { No associations with extrapyramidal symptoms } \\
\text { were noted }\end{array}$ \\
\hline $\begin{array}{l}\text { Prospective, } 12 \text { wks, } \\
\text { Japanese }(n=72)^{14}\end{array}$ & Paroxetine & No associations with nausea were noted \\
\hline $\begin{array}{l}\text { Prospective, } 12 \text { wks, } \\
\text { American }(\mathrm{n}=1655)^{16}\end{array}$ & Citalopram & $\begin{array}{l}\mathrm{L}_{\mathrm{A}} \mathrm{L}_{\mathrm{A}} \text { genotype associated with lower } \mathrm{ADR} \text { burden } \\
(7 \% \text { vs } 13 \%, \mathrm{p}=0.03) \text { vs other genotypes without } \\
\mathrm{L}_{\mathrm{A}} \text { allele }\end{array}$ \\
\hline
\end{tabular}

$\overline{\text { SSRI }}=$ selective serotonin reuptake inhibitor; $\mathrm{ADR}=$ adverse drug reaction .

shown to result in an increased maximum velocity of the enzyme-catalyzed reaction for serotonin reuptake compared with the $S$ allele. ${ }^{5}$ Therefore, lower levels of SERT-related transcription in patients with the $S$ allele could increase the proportion of reuptake transporters that are saturated; this effect may drastically increase synaptic serotonin levels and potentially result in adverse drug reactions (Figure 1 ).

In addition to SERTPR, the second intron of SLC6A4 contains a variable number of tandem repeats (VNTR) polymorphisms called STin $2 .{ }^{6}$ The variation in STin 2 consists of 9,10 and 12 repeats known as STin2.9, STin2.10, and STin2.12, respectively. Affinity for serotonin reuptake is lower among individuals homozygous for STin2.12 than among heterozygotes. ${ }^{6}$ Therefore, STin 2.12 could also increase serotonergic signaling and adverse drug reactions. Table 1 shows results of association studies focused on the relationship between polymorphisms of the serotonin transporter and SSRI-associated adverse drug reactions. ${ }^{7-16}$

\section{Serotonin Transporter Promoter Region} (SERTPR)

The population of one Japanese study consisted of 54 subjects; however, as only four of them had the LL genotype for SERTPR, investigators were not able to find any statistically significant associations. $^{7}$ One year later (2003), other researchers determined that the rates of insomnia and agitation were higher with the SS genotype than with others. ${ }^{8}$ They also performed logistic regression using baseline depression severity and anxiety-somatization factors as covariates. In this regression model, SS genotype was still a significant predictor associated with each outcome (insomnia $\mathrm{p}=0.02$, agitation $\mathrm{p}=0.01$ ).

In 2004, a somewhat contradictory finding suggested an association between increased SSRIinduced nighttime motor activity and the LL genotype. $^{9}$ Although actographically measured motor activity indicated a statistically significant difference, clinical assessments of retardation and agitation showed no difference between genotypes. Also in 2004, a large study demonstrated an 
Table 2. Summary of Studies Related to HTR2A Variants T102C and -1438 G/A

\begin{tabular}{|c|c|c|}
\hline $\begin{array}{l}\text { Polymorphism, Study } \\
\text { Design, Duration, } \\
\text { and Population }\end{array}$ & SSRI & Results \\
\hline \multicolumn{3}{|l|}{ T102C } \\
\hline $\begin{array}{l}\text { Retrospective, case- } \\
\text { control, Swedish } \\
(\mathrm{n}=19)^{13}\end{array}$ & $\begin{array}{l}\text { Fluoxetine, paroxetine, sertraline, } \\
\text { citalopram, fluvoxamine }\end{array}$ & $\begin{array}{l}\text { No associations with extrapyramidal symptoms were } \\
\text { noted }\end{array}$ \\
\hline $\begin{array}{l}\text { Prospective, } 12 \text { wks, } \\
\text { Japanese }(n=72)^{14}\end{array}$ & Paroxetine & No associations with nausea were noted \\
\hline $\begin{array}{l}\text { Prospective, } 8 \text { wks, } \\
\text { American }(n=120)^{18}\end{array}$ & Paroxetine & $\begin{array}{l}\text { CC genotype associated with more discontinuation } \\
\text { than CT and TT ( } 45 \% \text { vs } 15 \%, p=0.001) \text { and increased } \\
\text { ADR severity ( } \mathrm{p}=0.03)\end{array}$ \\
\hline \multicolumn{3}{|l|}{$-1438 \mathrm{G} / \mathrm{A}$} \\
\hline $\begin{array}{l}\text { Prospective, } 6 \text { wks, } \\
\text { Japanese }(\mathrm{n}=100)^{12}\end{array}$ & Paroxetine, fluvoxamine & $\begin{array}{l}\text { In paroxetine-treated patients, GG genotype associated } \\
\text { with more severe nausea ( } 30 \% \text { vs } 5 \%, p=0.014) \text { and all } \\
\text { ADRs }(70 \% \text { vs } 40 \%, p=0.043) \text { vs GA and AA genotypes }\end{array}$ \\
\hline $\begin{array}{l}\text { Prospective, } 6 \text { wks, } \\
\text { Japanese }(n=54)^{20}\end{array}$ & Fluvoxamine & No associations with nausea were noted \\
\hline $\begin{array}{l}\text { Prospective, } 12 \text { wks, } \\
\text { Japanese }(n=96)^{21}\end{array}$ & Fluvoxamine & $\begin{array}{l}\text { Single } G \text { allele increased risk of gastrointestinal adverse } \\
\text { effects by } 2.171 \text {-fold }(p=0.041) \text {; two } G \text { alleles increased } \\
\text { risk by } 2.926 \text {-fold }(p=0.008)\end{array}$ \\
\hline $\begin{array}{l}\text { Prospective, } \geq 6 \mathrm{wks} \\
\text { American }(\mathrm{n}=81)^{22}\end{array}$ & $\begin{array}{l}\text { Fluoxetine, paroxetine, sertraline, } \\
\text { citalopram, escitalopram }\end{array}$ & $\begin{array}{l}\text { GG genotype more likely than GA and AA genotypes to } \\
\text { have sexual dysfunction (odds ratio } 3.6, p=0.046 \text { ) }\end{array}$ \\
\hline
\end{tabular}

association between the number of $S$ alleles and the probability of discontinuation due to adverse drug reactions. ${ }^{10}$ The SS genotype was also associated with greater severity of adverse drug reactions.

Despite these early positive findings, a 2006 study in Australia and Malaysia involving 35 Caucasian and Asian subjects yielded no association between adverse drug reactions and the SS genotype. ${ }^{11}$ An evaluation of depressed Japanese patients randomly chosen to receive paroxetine or fluoxetine showed no associations of the SS genotype with discontinuation, nausea, or total adverse drug reactions. ${ }^{12}$ Swedish investigators retrospectively screened a national database to determine associations of SERTPR with SSRIinduced extrapyramidal symptoms and found none. ${ }^{13}$

In 2007, investigators reported the lack of associations between SERTPR polymorphisms and paroxetine-induced nausea. ${ }^{14}$ Researchers in the Netherlands conducted the largest study regarding SSRI-induced adverse drug reactions. ${ }^{15}$ Like the others, they found no statistically significant associations, but the SS and SL genotype tended to increased the risk of adverse drug reactions compared with the LL reference genotype.

The Sequenced Treatment Alternatives to Relieve Depression (STAR $\left.{ }^{*} \mathrm{D}\right)$ trial elucidated an association between a decreased burden of adverse drug reactions and the $\mathrm{L}_{\mathrm{A}}$ allele. ${ }^{16}$ In the total sample, the $\mathrm{L}_{\mathrm{A}} \mathrm{L}_{\mathrm{A}}$ genotype reduced the absolute risk of adverse drug reactions by $6 \%$. To our knowledge, this work is the largest adverse drug reaction association study of citalopram that was also designed to examine the effect of the additional $A>G$ substitution that SERTPR contains.

Serotonin Transporter, Second Intron Variable Number of Tandem Repeats (STin2)

In addition to the SLC6A4 SERTPR variant, STin2 may be associated with alternations in serotonergic neurotransmission. However, most studies of this variant have yielded no significant associations. For example, the aforementioned Dutch study also examined STin2 and found no statistically significant associations. ${ }^{15}$ A Japanese study found no associations among 54 patients because of a lack of subjects in the 10/10 genotype group. ${ }^{7}$ Given the findings from these two small studies, the role of STin2 in the development of SSRI-associated adverse drug reactions is still relatively unknown.

\section{Serotonin 2A Receptor Gene (HTR2A)}

The serotonin $2 \mathrm{~A}$ receptor encoded by HTR2A is the next logical target for pharmacogenetic studies because the mechanism of action of SSRIs is to increase synaptic serotonin, which acts on 
Table 3. Summary of Studies Related to HTR3A and HTR3B Variants

\begin{tabular}{|c|c|c|}
\hline $\begin{array}{l}\text { Polymorphism, Variants, } \\
\text { Study Design, Duration, Population }\end{array}$ & SSRI & Results \\
\hline $\begin{array}{l}\text { HTR3A C178T, HTR3B -100_102/AAG ins-del } \\
\text { Prospective, } 6 \text { wks, Japanese }(\mathrm{n}=100)^{12}\end{array}$ & $\begin{array}{l}\text { Paroxetine, } \\
\text { fluvoxamine }\end{array}$ & No associations with ADRs were noted \\
\hline $\begin{array}{l}\text { HTR3A A14371G, HTR3B -100_102/AAG ins-del } \\
\text { Prospective, } 6 \text { wks, Japanese }(\mathrm{n}=72)^{14}\end{array}$ & Paroxetine & $\begin{array}{l}\text { AAG deletion variant associated with more nausea } \\
\text { vs homozygous for AAG insertion allele } \\
(62 \% \text { vs } 38 \%, p=0.0028)\end{array}$ \\
\hline $\begin{array}{l}\text { HTR3A Prol6Ser and C195T, HTR3B Tyr129Ser } \\
\text { Prospective, } \geq 2 \mathrm{wks} \text {, Japanese }(\mathrm{n}=78)^{23}\end{array}$ & Paroxetine & $\begin{array}{l}\text { HTR3B Tyr/Tyr genotype increased risk of nausea } \\
\text { (odds ratio } 3.95, p=0.048 \text { ) }\end{array}$ \\
\hline
\end{tabular}

postsynaptic receptors, such as the $2 \mathrm{~A}$ subtype. Serotonin 2A receptors play an important role in agitation, insomnia, and sexual dysfunction. ${ }^{17}$

Several single-nucleotide polymorphisms (SNPs) have been characterized for HTR2A. The most frequently studied ones are T102C and -1438 G/A, where the CC genotype of $\mathrm{T} 102 \mathrm{C}$ is in perfect linkage disequilibrium with the GG genotype of $-1438 \mathrm{G} / \mathrm{A} .{ }^{18}$ The $\mathrm{C}$ allele of $\mathrm{T} 102 \mathrm{C}$ reduces expression of serotonin $2 \mathrm{~A}$ receptors, which could hasten their saturation and increase serotonergic activity, resulting in adverse drug reactions. ${ }^{19}$

Table 2 summarizes work done to elucidate the relationship between HTR2A receptor variation and SSRI-associated adverse drug reactions. ${ }^{12-14}$, $18,20-22$

\section{HTR2A Variants T102C (rs6313) and -1438G/A}

Researchers also evaluated associations between paroxetine-induced adverse drug reactions and the HTR2A T102C SNP. ${ }^{18}$ Paroxetinetreated patients with the CC genotype were more likely to discontinue treatment than the CT and TT genotypes, and their adverse drug reactions were also worse.

A 2007 evaluation of the frequency of nausea in Japanese patients treated with paroxetine showed no associations with the T102C variant. ${ }^{14}$ This was also true for other research conducted in Japan that yielded no significant relationship between the -1438 G/A genotype and fluvoxamine-induced nausea. ${ }^{20}$ In follow-up, other investigators found that a single $-1438 \mathrm{G}$ allele increased the risk of fluvoxamine-induced gastrointestinal adverse effects, whereas two copies of the $G$ allele increased the risk even more. ${ }^{21}$ Of interest, another group found no association with fluvoxamine, but they did find an association between the GG genotype and the severity of paroxetine-induced nausea and overall adverse drug reactions. ${ }^{12}$

Among patients who had been evaluated for SSRI-induced extrapyramidal symptoms, no associations with -1438 G/A were found. ${ }^{13}$ They were additionally screened for many other HTR2A polymorphisms, including Thr25Asn, C516T, and His452Tyr; none were associated the symptoms. However, given the small sample size, these results may not be surprising.

Investigators examined the relationship between the -1438 G/A variant and SSRI-associated sexual dysfunction using the Changes in Sexual Functioning Questionnaire, ${ }^{22}$ a validated instrument. They found an association between the GG genotype and SSRI-induced sexual dysfunction. This investigation is probably the largest pharmacogenetic study to focus on this adverse effect.

\section{Serotonin 3A Receptor Gene (HTR3A)}

The serotonin 3A receptor is another logical target for pharmacogenetic studies because the action of SSRI on synaptic serotonin also affects the $3 \mathrm{~A}$ subtype of postsynaptic receptors. Serotonin 3 receptors play an important role in mediating gastrointestinal adverse drug reactions, including diarrhea, nausea, and emesis. ${ }^{23}$

Several variants have been characterized for HTR3A; those most frequently studied are C195T and Prol6Ser $(\mathrm{C} 178 \mathrm{~T})$. The former, the C195T SNP, has not been shown to involve any functional change, but the nonsynonymous Prol6Ser mutation heightened expression of serotonin $3 \mathrm{~A}$ receptors. ${ }^{24}$ This increase in postsynaptic receptors could balance the rise in serotonin due to reuptake blockade and, ultimately, protect against adverse drug reactions. Table 3 summarizes the literature regarding serotonin 3 receptor variants and SSRI responses. ${ }^{12,14,23}$ From those studies, it appears that genetic variability in the HTR3A receptor 
may not be related to SSRI-associated adverse drug reactions.

\section{Serotonin 3B Receptor Gene (HTR3B)}

The postsynaptic serotonin $3 \mathrm{~B}$ receptor subtype is another candidate for pharmacogenetic studies given its position in the synapse. Several variants of HTR3B have been characterized, the most frequently studied of which are Tyr129Ser and the -100_-102AAG insertion-deletion. In terms of function, the AAG insertion-deletion may alter the structure and translational efficiency of messenger RNA, whereas consequences of the Tyr129Ser nonsynonymous mutation are not well characterized. ${ }^{25}$

In the field of oncology, the AAG deletion has been associated with an increased frequency of chemotherapy-induced emesis. This adverse event may be due to a decrease in receptor translation that results in fewer postsynaptic receptors, thereby making them more saturated, with increased serotonergic activity and a higher frequency of adverse drug reactions. ${ }^{26}$

In psychiatry, several research groups have examined the relationship between gastrointestinal adverse effects and $H T R 3 B$ receptor genetic variability, as summarized in Table 3.12, 14, 23 Applying a logistic regression model, the first group reported an association between the Tyr/Tyr genotype of Tyr129Ser and a heightened risk of paroxetine-induced nausea. ${ }^{23}$ In 2007, investigators showed an association between the -100_-102AAG deletion variant and a higher frequency of paroxetine-induced nausea but no association with Tyr129Ser. ${ }^{14}$ They also screened for and tested many other polymorphisms and found no significant associations. Given these findings, the role of the HTR3B receptor and SSRI-associated nausea is still unknown.

\section{Tryptophan Hydroxylase Gene (TPH)}

Tryptophan hydroxylase, or TPH, is the ratelimiting enzyme that catalyzes synthesis of serotonin from tryptophan. Increased function of this enzyme could raise serotonin levels and, therefore, potentiate serotonergic effects and adverse drug reactions due to SSRIs. The A allele of the tryptophan hydroxylase A218C polymorphism has been associated with a slowed therapeutic response to fluvoxamine. ${ }^{27}$ However, whether was this is due to a functional change in the enzyme is unclear.

In 2002, scientists investigated the relationship between the tryptophan hydroxylase A218C variant and fluvoxamine-induced nausea in a 6week prospective study. ${ }^{7}$ They found no significant associations in their population of 54 Japanese patients.

\section{Dopaminergic Genes}

In addition to serotonergic genes, dopaminergic genes have been examined in relation to SSRIassociated adverse drug reactions. Data from imaging studies of the human striatum have associated the Al allele of the dopamine 2 receptor gene (DRD2) Taq1A polymorphism with reduced binding of the D2 receptor. ${ }^{28}$ This lower striatal density of $D_{2}$ receptors among Al allele carriers may mean that the receptors could be more rapidly saturated by dopamine. Because several SSRIs have binding affinity for the dopamine reuptake transporter (DAT), patients with the DRD2 TaqlA Al allele could be at particular risk for having dopaminergicassociated adverse drug reactions if they use SSRIs.

Several dopaminergic genes were investigated in the 2006 retrospective study of 20 Swedish patients. ${ }^{13}$ The DRD2 TaqlA A1 allele was associated with SSRI-induced extrapyramidal symptoms. The group of patients who had these symptoms included significantly more carriers of the Al allele than a control group pooled from the European literature ( $32 \%$ vs $15 \%, \mathrm{p}=0.017$ ).

In addition to the DRD2 TaqlA variant, both the DAT VNTR and the dopamine 3 receptor (DRD3) Mscl restriction fragment length polymorphisms have not been not associated with SSRI-induced adverse drug reactions, specifically extrapyramidal symptoms. Therefore, variation in the dopaminergic system is unlikely to be a major contributor to these reactions.

\section{Glutamatergic Genes}

Scientists have recognized potential effects of the glutamate system on treatment-emergent adverse drug reactions. Because glutamate is one of the most abundant excitatory neurotransmitters in the central nervous system, genetic variation in glutamate receptors may influence neurotransmission in a way not yet fully appreciated.

Despite this lack of a clear mechanism, recent genomewide association analyses in the STAR*D cohort revealed a potential link between ionotropic glutamate receptors and suicidal ideation. The largest pharmacogenomics association analysis related to SSRI treatment-emergent suicidal ideation was reported in 2007. ${ }^{29}$ The study 
population of 1862 was derived from STAR*D subjects whose genotypes were evaluated for 68 candidate genes with 768 SNPs. The CC genotype at SNP rs2518224 of GRIK2, which encodes glutamate kainate receptor subunit GluR6, was associated with treatment-emergent suicidal ideation, as measured by using the Quick Inventory of Depressive SymptomatologySubject Rated (QIDS-SR) tool (odds ratio 8.23, permutation $\mathrm{p}<0.003)$. In addition, the $G$ allele at SNP rs4825476 of GRIA3, which encodes glutamate AMPA receptor subunit AMPA3, was also associated with suicidal ideation (odds ratio 1.94, permutation $\mathrm{p}<0.01$ ).

These data are intriguing and will help us learn more about the role of glutamatergic neurotransmission in depression and the occurrence of treatment-emergent suicidal ideation.

\section{Monoaminergic Genes}

\section{Monoamine Oxidase A Gene (MAOA)}

Monoamine oxidase $\mathrm{A}$ is an enzyme that catalyzes oxidation of all monoamine neurotransmitters. Monoamine oxidase inhibitors were among the first antidepressants available for the treatment of major depression. Therefore, decreased function of this enzyme may be associated with increased monoaminergic effects from SSRIs.

Overall, MAOA polymorphisms have been examined in a variety of association studies involving anger and anxiety. However, the first study performed to directly assess functional effects elucidated no significant differences among them. ${ }^{30}$ In 2003, an investigation of the MAOA-VNTR polymorphism found that patients with low plasma levels of fluvoxamine appeared to be more pharmacodynamically sensitive to nausea. ${ }^{20}$ Therefore, investigators extracted a post hoc subgroup of 35 patients who had belowaverage plasma levels, and the MAOA-VNTR allele 1 was more common in patients without nausea $(p=0.02)$. However, this study has not been replicated; thus, the role of MAOA-VNTR in SSRI-associated adverse drug reactions is still unknown.

Cyclic Adenosine 3',5'-Monophosphate Response Element Binding Protein 1 Gene (CREB1)

The cyclic adenosine $3^{\prime}, 5^{\prime}$-monophosphate (cAMP) response element binding protein, CREB1, binds cAMP response elements and induces transcription after stimulation of the
cAMP pathway downstream of the monoamine receptors.

In 2007, an association analysis involved 1447 $\mathrm{STAR}^{*} \mathrm{D}$ subjects whose genotypes were examined at five SNPs from regions in and surrounding the candidate gene CREB1. ${ }^{31}$ In a subgroup of 539 men, SNP rs4675690 (which is 3' to the coding region) was associated with treatment-emergent suicidal ideation in the first 30 days (odds ratio 2.3 , permutation $\mathrm{p}<0.003$ ), as measured by using the Quick Inventory of Depressive Symptomatology-Clinician Rated (QIDS-C).

In subsequent studies, this CREB1 SNP was also associated with brain activation of neural networks implicated in processing aversion responsiveness to angry faces. ${ }^{32}$ These results, taken with those presented earlier, ${ }^{29}$ offer us new directional hypotheses concerning SSRI-associated adverse drug reactions.

\section{Metabolic Genes}

\section{Cytochrome P450 2D6 Gene (CYP2D6)}

A substantial part of the literature has focused on pharmacokinetic changes that may occur as a result of genetic variability in the CYP isoenzyme system, specifically CYP2D6. Because this isoenzyme is well characterized in terms of its specific substrates and inhibitors or inducers, it would make sense that changes in drug metabolism may alter outcomes. However, identifying exactly how each CYP2D6 variant should be classified in terms of metabolic status has proven difficult. The theory regarding SSRI-related adverse drug reactions and CYP2D6 metabolism was based on the premise that genetic variants conferring poor-metabolizer status should raise serum concentrations of SSRIs, possibly potentiating the serotonergic effects and increase adverse drug reactions. The Evaluation of Genomic Applications in Practice and Prevention (EGAPP) Working Group recently cast doubt on this theory, citing a lack of evidence to support or refute the theoretical benefit of CYP2D6 genotyping in the treatment of depression with SSRIs. $^{3}$

In 2003, 120 elderly patients were grouped as poor (homozygous null), intermediate (null allele and $* 41,{ }^{*} 10$, or ${ }^{*} 9$ ), ultrarapid $\left({ }^{*} 1\right.$ or $* 2$ duplicates), or extensive (all other) metabolizers. ${ }^{18}$ For analysis, the poor- and intermediatemetabolic groups were combined and compared with extensive and ultrarapid metabolizers. Overall, no significant differences in adverse drug reaction rates were found between these groups. 
Table 4. Summary of Studies Related to Cytochrome P450 2D6 Metabolic Status

\begin{tabular}{|c|c|c|}
\hline $\begin{array}{l}\text { Polymorphism, Study } \\
\text { Design, Duration, } \\
\text { and Population }\end{array}$ & SSRI & Results \\
\hline \multicolumn{3}{|l|}{ PM, EM } \\
\hline $\begin{array}{l}\text { Retrospective, case- } \\
\text { control, Swedish } \\
(\mathrm{n}=19)^{13}\end{array}$ & $\begin{array}{l}\text { Fluoxetine, paroxetine, } \\
\text { sertraline, citalopram, } \\
\text { fluvoxamine }\end{array}$ & $\begin{array}{l}\text { No associations with extrapyramidal symptoms } \\
\text { were noted }\end{array}$ \\
\hline $\begin{array}{l}\text { Prospective, } 12 \text { wks, } \\
\text { Japanese }(\mathrm{n}=72)^{14}\end{array}$ & Paroxetine & No associations with nausea were noted \\
\hline $\begin{array}{l}\text { Prospective, } \geq 2 \text { wks } \\
\text { Japanese }(n=78)^{23}\end{array}$ & Paroxetine & No associations with nausea were noted \\
\hline $\begin{array}{l}\text { Prospective, } 6 \text { wks, } \\
\text { New Zealander }(n=65)^{33}\end{array}$ & Fluoxetine & No associations with ADRs were noted \\
\hline \multicolumn{3}{|l|}{ LM, NM } \\
\hline $\begin{array}{l}\text { Prospective, } 12 \text { wks, } \\
\text { Japanese }(\mathrm{n}=96)^{21}\end{array}$ & Fluvoxamine & $\begin{array}{l}\text { LMs associated with a higher risk of gastrointestinal } \\
\text { adverse effects than NMs (hazard ratio } 1.821 \text {, } \\
\mathrm{p}=0.043 \text { ) }\end{array}$ \\
\hline \multicolumn{3}{|l|}{ PM, IM, EM } \\
\hline $\begin{array}{l}\text { Prospective, } 6 \text { wks, } \\
\text { Japanese }(\mathrm{n}=49)^{34}\end{array}$ & Fluvoxamine & No associations with nausea were noted \\
\hline \multicolumn{3}{|l|}{ PM, IM, EM, UM } \\
\hline $\begin{array}{l}\text { Prospective, } 8 \text { wks, } \\
\text { American }(\mathrm{n}=120)^{18}\end{array}$ & Paroxetine & $\begin{array}{l}\text { No associations with discontinuation or severity } \\
\text { of ADRs were noted }\end{array}$ \\
\hline
\end{tabular}

SSRI = selective serotonin reuptake inhibitor; $\mathrm{ADR}=$ adverse drug reaction; $\mathrm{PM}=$ poor metabolizer; $\mathrm{EM}=$ extensive metabolizer; $\mathrm{IM}=$ intermediate metabolizer; $\mathrm{UM}=$ ultrarapid metabolizer; $\mathrm{LM}=$ low metabolizer; $\mathrm{NM}=$ normal metabolizer.

A study in 2004 addressed fluoxetine-induced adverse drug reactions among patients in New Zealand. ${ }^{33}$ It uncovered no significant difference between extensive $\left({ }^{*} 1\right.$ with ${ }^{*} 1, * 2, * 9$, or $\left.{ }^{*} 10\right)$ and poor $(* 4 / * 4, * 4 / * 5)$ metabolizers. Follow-up investigation in Japanese patients demonstrated no association between metabolic status and fluvoxamine-induced nausea or plasma levels of fluvoxamine. ${ }^{34}$ Subjects were stratified as extensive $\left({ }^{*} 1 /{ }^{*} 1\right)$, intermediate $\left({ }^{*} 1 /{ }^{*} 5,{ }^{*} 1 /{ }^{*} 10\right)$, or poor $\left(* 5 / * 10,{ }^{*} 10 /{ }^{*} 10\right)$ metabolizers. Further research in Japanese patients in 2006 revealed no significant difference between paroxetineinduced nausea and extensive $\left({ }^{*} 1 /{ }^{*} 1,{ }^{*} 1 /{ }^{*} 10\right)$ or poor $(* 1 / * 5, * 5 / * 10, * 10 / * 10)$ metabolism. ${ }^{23}$ Among Swedish patients with SSRI-induced extrapyramidal symptoms, nonfunctional allelic frequency $\left({ }^{*} 4\right)$ did not statistically differ from that observed in the European population. ${ }^{13}$ Overall, the authors inferred that metabolic status did not affect the risk of extrapyramidal symptoms. A Cox-regression study in Japan showed a significantly higher risk of fluvoxamineinduced gastrointestinal adverse effects among low metabolizers $(* 1 / * 5, * 5 / * 10, * 10 / * 10)$ compared with normal metabolizers $\left({ }^{*} 1 /{ }^{*} 1\right.$, $* 1 / * 10){ }^{21}$

Table 4 summarizes pharmacogenetic investi- gations performed to examine the role of CYP2D6 on SSRI-associated adverse drug reactions. ${ }^{13}, 14,18$, 21, 23, 33, 34 Data from most studies specifically addressing the relationship between differences in CYP2D6 metabolic activity and SSRI-associated adverse drug reactions have been negative. Therefore, although this isoenzyme is extremely important in drug metabolism, its role in the development of these adverse drug reactions is still debatable. This fact may limit the utility of incorporating specific testing for CYP2D6 into clinical practice.

\section{Cytochrome P450 2C19 Gene (CYP2C19)}

Given its role in the metabolism of antidepressants, CYP2C19 has also been examined in relation to SSRI-associated adverse drug reactions. Examining 53 Chinese patients in 2006, scientists found no significant difference in citalopram-induced adverse effects among poor $(* 2 / * 2, * 2 / * 3, * 3 / * 3)$, extensive homozygous $\left({ }^{*} 1 /{ }^{*} 1\right)$, and extensive heterozygous $\left({ }^{*} 1 /{ }^{*} 2\right.$ or *3) metabolizers. ${ }^{35}$ However, oral clearance of citalopram was lower in poor metabolizers than in extensive homozygous $(p=0.001)$ or heterozygous $(\mathrm{p}=0.020)$ metabolizers. Despite these potential pharmacogenetic differences, the 
clinical relevance of the measurable change in clearance was not appreciable.

\section{Emerging Trends}

Although conflicting results for associations with efficacy have diluted most pharmacogenetic studies of SSRIs, clear trends seem to have emerged with certain polymorphisms and the risk of adverse drug reactions. Multiple studies have demonstrated reproducible associations between SSRI-induced adverse drug reactions and the $G$ allele of the HTR2A -1438G/A variant and the short (S) allele of SLC6A4 SERTPR. On the other hand, no clear associations have been established between CYP2D6 and the risk of adverse drug reactions. However, novel polymorphisms associated with dopaminergic, serotonergic, and glutaminergic neurotransmission must be investigated more extensively to examine the associations found and to continue generating hypotheses regarding the role of these neurotransmitters in SSRI treatment. Newly published data have shown an association between genetic variation in the drug transport protein P-glycoprotein and the antidepressant response. ${ }^{36}$ However, the relationship between P-glycoprotein and adverse drug reactions is unknown.

\section{Conclusion}

The literature regarding the pharmacogenetics of SSRI-associated adverse drug reactions is emerging and currently dominated by retrospective studies of relatively few subjects with little control over how the drugs were given. In addition, our understanding of the true mechanism of action for SSRIs is evolving as we learn of additional receptors and transporters that the drugs target. Large, recent data sets such as that collected in the STAR*D trial may offer additional insights into mechanisms underlying adverse drug reactions, as well as responses to them. However, results of studies like these are just starting to emerge.

In the future, pharmacogenetic association studies will benefit from rational mechanisms that relate functional changes to the pharmacology of adverse drug reactions. As associations continue to be elucidated and as studies are well replicated, the next logical step will be to investigate the use of prospective genotyping to guide SSRI pharmacotherapy and evaluate therapeutic responses. Maybe one day soon, pharmacogenetic studies will help us realize the ultimate goal of delivering personalized medical care.

\section{References}

1. IMS Health Inc. 2007 top 10 therapeutic classes by U.S. dispensed prescriptions. IMS national prescription audit plus. Available from http://wwwl.imshealth.com/ims/portal/front/ articleC/0,2777,6599_80411808_80413635,00.html. Accessed September 10, 2008

2. Serretti A, Artioli P. The pharmacogenomics of selective serotonin reuptake inhibitors. Pharmacogenomics J 2004:4(4):233-44.

3. Evaluation of Genomic Applications in Practice and Prevention (EGAPP) Working Group. Recommendations from the EGAPP working group: testing for cytochrome P450 polymorphisms in adults with nonpsychotic depression treated with selective serotonin reuptake inhibitors. Genet Med 2007:9(12):819-25.

4. Lesch KP, Gutknect L. Pharmacogenetics of the serotonin transporter. Prog Neuropsychopharmacol Biol Psychiatry 2005;29(6):1062-73.

5. Greenberg BD, Tolliver TJ, Huang SJ, Li Q, Bengel D, Murphy DL. Genetic variation in the serotonin transporter promoter region affects serotonin uptake in human blood platelets. Am J Med Genet 1999;88(1):83-7.

6. Kaiser R, Müller-Oerlinghausen B, Filler D, et al. Correlation between serotonin uptake in human blood platelets with the 44-bp polymorphism and the 17-bp variable number of tandem repeat of the serotonin transporter. Am J Med Genet 2002;114(3):323-8.

7. Takahashi H, Yoshida K, Ito K, et al. No association between the serotonergic polymorphisms and incidence of nausea induced by fluvoxamine treatment. Eur Neuropsychopharmacol 2002;12(5):477-81

8. Perlis RH, Mischoulon D, Smoller JW, et al. Serotonin transporter polymorphisms and adverse effects with fluoxetine treatment. Biol Psychiatry 2003;54(9):879-83.

9. Putzhammer A, Schoeler A, Rohrmeier T, Sand P, Hajak G, Eichhammer P. Evidence of a role for the 5-HTTLPR genotype in the modulation of motor response to antidepressant treatment. Psychopharmacology (Berl) 2005;178(2-3):303-8.

10. Murphy GM Jr, Hollander SB, Rodrigues HE, Kremer C, Schatzberg AF. Effects of the serotonin transporter gene promoter polymorphism on mirtazapine and paroxetine efficacy and adverse events in geriatric major depression. Arch Gen Psychiatry 2004;61(11):1163-9.

11. Ng CH, Easteal S, Tan S, Schweitzer I, Ho BK, Aziz S. Serotonin transporter polymorphisms and clinical response to sertraline across ethnicities. Prog Neuropsychopharmacol Biol Psychiatry 2006;30(5):953-7.

12. Kato M, Fukuda T, Wakeno M, et al. Effects of the serotonin type $2 \mathrm{~A}, 3 \mathrm{~A}$ and $3 \mathrm{~B}$ receptor and the serotonin transporter genes on paroxetine and fluvoxamine efficacy and adverse drug reactions in depressed Japanese patients. Neuropsychobiology 2006;53(4):186-95.

13. Hedenmalm K, Güzey C, Dahl ML, Yue QY, Spigset O. Risk factors for extrapyramidal symptoms during treatment with selective serotonin reuptake inhibitors, including cytochrome P-450 enzyme, and serotonin and dopamine transporter and receptor polymorphisms. J Clin Psychopharmacol 2006; 26(2):192-7.

14. Tanaka M, Kobayashi D, Murakami Y, et al. Genetic polymorphisms in the 5-hydroxytryptamine type 3B receptor gene and paroxetine-induced nausea. Int J Neuropsychopharmacol 2008;11(2):261-7.

15. Smits K, Smits L, Peeters F, et al. Serotonin transporter polymorphisms and the occurrence of adverse events during treatment with selective serotonin reuptake inhibitors. Int Clin Psychopharmacol 2007;22(3):137-43.

16. Hu XZ, Rush AJ, Charney D, et al. Association between a functional serotonin transporter promoter polymorphism and citalopram treatment in adult outpatients with major depression. Arch Gen Psychiatry 2007;64(7):783-92.

17. Stahl S. Essential psychopharmacology: neuroscientific basis and practical applications. New York: Cambridge University 
Press, 2000.

18. Murphy GM Jr, Kremer C, Rodrigues HE, Schatzberg AF. Pharmacogenetics of antidepressant medication intolerance. Am J Psychiatry 2003;160(10):1830-5.

19. Polesskaya OO, Sokolov BP. Differential expression of the "C" and " $\mathrm{T}$ " alleles of the 5-HT2A receptor gene in the temporal cortex of normal individuals and schizophrenics. J Neurosci Res 2002;67(6):812-22.

20. Yoshida K, Naito $\mathrm{S}$, Takahashi $\mathrm{H}$, et al. Monoamine oxidase A gene polymorphism, 5-HT 2A receptor gene polymorphism and incidence of nausea induced by fluvoxamine. Neuropsychobiology 2003;48(1):10-13.

21. Suzuki Y, Sawamura K, Someya T. Polymorphisms in the 5hydroxytryptamine $2 \mathrm{~A}$ receptor and cytochromeP4502D6 genes synergistically predict fluvoxamine-induced side effects in Japanese depressed patients. Neuropsychopharmacology 2006;31(4):825-31.

22. Bishop JR, Moline J, Ellingrod VL, Schultz SK, Clayton AH. Serotonin 2A-1438 G/A and G-protein beta3 subunit C825T polymorphisms in patients with depression and SSRI-associated sexual side-effects. Neuropsychopharmacology 2006;31(10): 2281-8

23. Sugai T, Suzuki Y, Sawamura K, Fukui N, Inoue Y, Someya T. The effect of 5-hydroxytryptamine $3 \mathrm{~A}$ and $3 \mathrm{~B}$ receptor genes on nausea induced by paroxetine. Pharmacogenomics J 2006;6(5):351-6.

24. Niesler B, Flohr T, Nöthen MM, et al. Association between the $5^{\prime}$ UTR variant $\mathrm{C} 178 \mathrm{~T}$ of the serotonin receptor gene HTR3A and bipolar affective disorder. Pharmacogenetics 2001;11(6): 471-5.

25. Frank B, Niesler B, Nöthen MM, et al. Investigation of the human serotonin receptor gene HTR3B in bipolar affective and schizophrenic patients. Am J Med Genet B Neuropsychiatr Genet 2004;131B(1):1-5.

26. Tremblay PB, Kaiser R, Sezer O, et al. Variations in the 5hydroxytryptamine type $3 \mathrm{~B}$ receptor gene as predictors of the efficacy of antiemetic treatment in cancer patients. J Clin Oncol 2003;21(11):2147-55
27. Serretti A, Zanardi R, Rossini D, Cusin C, Lilli R, Smeraldi E. Influence of tryptophan hydroxylase and serotonin transporter genes on fluvoxamine antidepressant activity. Mol Psychiatry 2001;6(5):586-92

28. Thompson J, Thomas N, Singleton A, et al. D2 dopamine receptor gene (DRD2) Taql A polymorphism: reduced dopamine D2 receptor binding in the human striatum associated with the Al allele. Pharmacogenetics 1997;7(6):479-84.

29. Laje G, Paddock S, Manji H, et al. Genetic markers of suicidal ideation emerging during citalopram treatment of major depression. Am J Psychiatry 2007;164(10):1530-8.

30. Balciuniene J, Emilsson L, Oreland L, Pettersson U, Jazin E. Investigation of the functional effect of monoamine oxidase polymorphisms in human brain. Hum Genet 2002;110(1):1-7.

31. Perlis RH, Purcell S, Fava M, et al. Association between treatment-emergent suicidal ideation with citalopram and polymorphisms near cyclic adenosine monophosphate response element binding protein in the STAR*D study. Arch Gen Psychiatry 2007;64(6):689-97.

32. Perlis RH, Holt DJ, Smoller JW, et al. Association of a polymorphism near CREBl with differential aversion processing in the insula of healthy participants. Arch Gen Psychiatry 2008;65(8):882-92.

33. Roberts RL, Mulder RT, Joyce PR, Luty SE, Kennedy MA. No evidence of increased adverse drug reactions in cytochrome P450 CYP2D6 poor metabolizers treated with fluoxetine or nortriptyline. Hum Psychopharmacol 2004;19(1):17-23.

34. Gerstenberg G, Aoshima T, Fukasawa T, et al. Relationship between clinical effects of fluvoxamine and the steady-state plasma concentrations of fluvoxamine and its major metabolite fluvoxamino acid in Japanese depressed patients. Psychopharmacology (Berl) 2003;167(4):443-8.

35. Yin OQ, Wing YK, Cheung Y, et al. Phenotype-genotype relationship and clinical effects of citalopram in Chinese patients. J Clin Psychopharmacol 2006;26(4):367-72.

36. Uhr M, Tontsch A, Namendorf C, et al. Polymorphisms in the drug transporter gene $\mathrm{ABCB} 1$ predict antidepressant treatment response in depression. Neuron 2008;57(2):203-9. 